\title{
GROWTH, MOLT AND SURVIVAL OF PALAEMONETES ARGENTINUS (DECAPODA, CARIDEA) UNDER DIFFERENT LIGHT-DARK CONDITIONS
}

\author{
Ana Cristina Díaz ${ }^{1,2}$ \\ Liliana G. Sousa ${ }^{1}$ \\ Elena I. Cuartas ${ }^{3}$ \\ Ana María Petriella ${ }^{1,4}$
}

\begin{abstract}
Growth, survival and molting rate in Palaemonetes argentinus Nobili, 1901 were compared under different light-dark conditions. During 80 days, 150 immatures of both sexes (initial mean weight $0.09 \pm 0.002 \mathrm{~g}$ ), from Los Padres lagoon, Mar del Plata, Argentina, were maintained in aquaria at $19 \pm 0.4^{\circ} \mathrm{C}$ under three light conditions: $0: 24,10: 14$ and 13:11 (L-D). They were fed daily on an artificial diet ( $45 \%$ proteins, $17.2 \%$ lipids, $7 \%$ water, $7 \%$ ash). Good weight increment was obtained with the three treatments, finding a positive linear correlation between mean weight and time $(0: 24$, $\mathrm{r}=0.97 ; 10: 14, \mathrm{r}=0.99 ; 13: 11, \mathrm{r}=0.98)$. There were no significant differences in the percentage increment in mean weight among the treatments $(0: 24,19.3 \% ; 10: 14,29.3 \%$ and $13: 11,26.5 \%)$ $(\mathrm{p}<0.05)$. Molting rate was significantly higher at a long-day photoperiod $(\mathrm{MR}=1.7)$ than at a shortday $(\mathrm{MR}=0.6)$ or continuous dark condition $(\mathrm{MR}=0.3)(\mathrm{p}<0.05)$. The lowest survival was found in animals maintained under 13:11 L-D conditions (77\%), being statistically different of the other two treatments $(92 \%$ and $89 \%$ at $10: 14$ and $0: 24$, respectively) $(\mathrm{p}<0.05)$. These results suggest that the best growth and survival in $P$. argentinus result with a 10:14 L-D cycle, and that the growth is less affected by photoperiod than molting rate and survival.
\end{abstract}

KEYWORDS. Growth, molt, photoperiod, Crustacea, Palaemonidae.

\section{INTRODUCTION}

The animal physiology comprises many rhythmic functions where the circadian cycles influence is essential to maintain appropriate timing relationships between these functions and the environment. In many species, seasonal changes in day length (photoperiod) act as an external temporal clue to initiate a series of physiological processes. As result, certain events (molting, reproduction, hatching) are restricted to specific periods of the year. These photoperiodically controlled responses imply a capacity of the organisms to distinguish between short and long days and therefore

1. Departamento de Ciencias Marinas, Facultad de Ciencias Exactas y Naturales, Universidad Nacional de Mar del Plata (UNMP), Funes 3350, B7602AYL, Mar del Plata, Argentina.

2. Comisión de Investigaciones Científicas de la Pcia. de Buenos Aires.

3. Departamento de Biología, Facultad de Ciencias Exactas y Naturales, UNMP.

4. CONICET 
measure geophysical time; this measurement seems to be based, at least in some species, on endogenous rhythms (SAUNDERs, 1975; HofFMAN, 1981; CASTAÑóN-CERVANTES et al., 1995).

Survival and growth of decapods can be affected by a variety of environmental factors including temperature, oxygen concentration, salinity and light (MASON, 1978; AIKEN et al., 1983; TIDWELL et al., 1996). Intensity variations, spectral composition, light polarization and photophase duration affect the growth and reproduction in crustaceans. Some studies have compared the effect of constant conditions with the daily light-dark cycles, with variable results (DALLEY, 1980). Artificial light is used as a tool, in species adapted to diverse environments and at different latitudes, to investigate the physiological dynamics which could be involved in determining distribution and adaptation patterns of these animals (FAnJul-Moles et al., 1998). The daily cycle of light and dark, and the seasonal changes in the proportions of light-dark are most likely to be of significance in the crustacean life (DALLEY, 1980). Seasonal effects on growth, molting, metabolic rate, induction of anecdysis, maturation of gonads and sex determination may be under photoperiodic control in some species (PASSANo, 1960; AiKen, 1969; SEAGal, 1970; Aiken et al., 1983).

Palaemonetes argentinus Nobili, 1901 is a species of ecological interest due to its abundance in ponds and lagoons of Argentina and south of Brazil (BOND-BucKuP \& BuCKUP, 1989) and because it is part of the diet of several species of fish and birds (Destefanis \& Freyre, 1972).

The objective was to compare growth, survival and molting rate in individuals of $P$. argentinus maintained at different light-dark conditions.

\section{MATERIAL AND METHODS}

Immature individuals of both sexes (initial mean weight $0.092 \pm 0.0026 \mathrm{~g}$ ), collected from Los Padres lagoon, Mar del Plata, Argentina $\left(37^{\circ} 57^{\prime} \mathrm{S}, 57^{\circ} 44^{\prime} \mathrm{W}\right)$ were maintained during 80 days (MarchMay) in nine 30 litres aquaria with a sand and shell filter and gently aerated freshwater. Freshwater fit for human consumption $(\mathrm{pH}=7.6)$ was used in the experiment. Mean total water hardness $\left(\mathrm{as} \mathrm{CaCO}_{3}\right)$ was $110 \mathrm{mg} .1^{-1}$; TDS, 955mg. $1^{-1}$; nitrite, $0.01 \mathrm{mg} .1^{-1}$; nitrate, $0.01 \mathrm{mg} .1^{-1}$ and unionised ammonia, 0.01 mg. $1^{-1}$. Twenty five animals were held communally in each aquarium under three light conditions: $0: 24,10: 14$ and 13:11 (L-D). The first photoperiod was used as an extreme condition and the latter ones correspond to the average light hours in autumn and spring, respectively, at this latitude. Each treatment was carried out in triplicate and using natural light in the light treatments, covering the aquaria with black boxes after the required photophase. The complete darkness was kept using black glass aquaria covered with black boxes. The temperature was maintained at $19 \pm 0.4^{\circ} \mathrm{C}$, which was found to be the optimal for growth and survival of P. argentinus (Díaz et al., 1998).

The individuals were fed daily on a pelletized diet prepared in the laboratory (45\% proteins, $17.2 \%$ lipids, $7 \%$ water, $7 \%$ ash), providing about $10 \%$ of body weight (DíAz et al., 2001). Prior to feeding, exuviae were collected; presence of any dead prawn was recorded and any excess of food removed to preserve water quality. Samples were deposited in Departamento de Ciências Marinas, Universidad Nacional de Mar del Plata, Argentina. Molting rate was determined according to GuARY et al. (1974): $\mathrm{MR}=$ number of molts/initial number of individuals. The animals were weighed at the beginning of the experiment and every 20 days $(0.001 \mathrm{~g})$. The results were analyzed using linear regression models and the following statistical tests were performed: ANOVA, ANCOVA, Bartlett, Cochran and $x^{2}$ (SOKAL \& RoHLF, 1995).

\section{RESULTS}

A significant weight increment was obtained with the three treatments (tab. I), and the mean weight was plotted against time determining a linear adjustment (fig. 1). The 
Table I. Growth, survival and molting rate of Palaemonetes argentinus maintained under different photophases $(\% \Delta \mathrm{w}$, percentage increment in mean weight; comb, combined values of three aquaria; $\mathrm{MR}$, molting rate; ni, initial number of individuals; s, standard error; S, survival; xi and xf, initial and final mean weight).

\begin{tabular}{|c|c|c|c|c|c|c|c|c|c|c|c|}
\hline $\begin{array}{l}\text { Light-dark } \\
\text { condition }\end{array}$ & Aquarium & ni & xi (g) & \pm & s & $x f(g)$ & \pm & $\mathrm{s}$ & S (\%) & MR & $\% \Delta \mathrm{w}$ \\
\hline \multirow{4}{*}{$0: 24$} & 1 & 25 & 0.096 & \pm & 0.0150 & 0.116 & \pm & 0.0226 & 88.0 & 0.60 & 20.80 \\
\hline & 2 & 25 & 0.091 & \pm & 0.0136 & 0.116 & \pm & 0.0285 & 96.0 & 0.16 & 27.15 \\
\hline & 3 & 25 & 0.092 & \pm & 0.0155 & 0.121 & \pm & 0.0298 & 84.0 & 0.20 & 31.52 \\
\hline & Combined & 75 & 0.093 & \pm & 0.0026 & 0.118 & \pm & 0.0028 & 89.3 & 0.32 & 26.49 \\
\hline \multirow[t]{4}{*}{$10: 14$} & 1 & 25 & 0.091 & \pm & 0.0173 & 0.122 & \pm & 0.0204 & 88.0 & 0.96 & 34.06 \\
\hline & 2 & 25 & 0.094 & \pm & 0.0179 & 0.116 & \pm & 0.0242 & 92.0 & 0.32 & 23.40 \\
\hline & 3 & 25 & 0.092 & \pm & 0.0159 & 0.120 & \pm & 0.0305 & 96.0 & 0.44 & 30.43 \\
\hline & Combined & 75 & 0.092 & \pm & 0.0015 & 0.119 & \pm & 0.0030 & 92.0 & 0.57 & 29.30 \\
\hline \multirow[t]{4}{*}{$13: 11$} & 1 & 25 & 0.092 & \pm & 0.0168 & 0.117 & \pm & 0.0123 & 84.0 & 2.20 & 27.17 \\
\hline & 2 & 25 & 0.087 & \pm & 0.0186 & 0.110 & \pm & 0.0326 & 60.0 & 1.80 & 26.43 \\
\hline & 3 & 25 & 0.095 & \pm & 0.0119 & 0.099 & \pm & 0.0195 & 88.0 & 1.04 & 04.21 \\
\hline & Combined & 75 & 0.091 & \pm & 0.0040 & 0.108 & \pm & 0.0091 & 77.3 & 1.68 & 19.27 \\
\hline
\end{tabular}

regression equations are: 00:24 (L-D), mean weight $(\mathrm{g})=0.0926+0.0003$ time (days), $\mathrm{r}=0.97 ; 10: 14$, mean weight $(\mathrm{g})=0.0916+0.0004$ time (days), $\mathrm{r}=0.99 ; 13: 11$, mean weight $(\mathrm{g})=0.0926+0.0002$ time (days), $\mathrm{r}=0.98$. ANCOVA showed that all slopes and intercepts are not significantly different $(\mathrm{p}<0.05)$.

No significant differences in the mean weight increment were found among the treatments $(0: 24,19.30 \% ; 10: 14,29.3 \% ; 13: 11,26.5 \%)(\mathrm{p}<0.05)$. The daily mean weight increment, in the different treatments, was: $0.24 \%(13: 11), 0.33 \%(0: 24)$ and $0.36 \%(10: 14)$. Significant differences were found among the molt rates obtained with the three
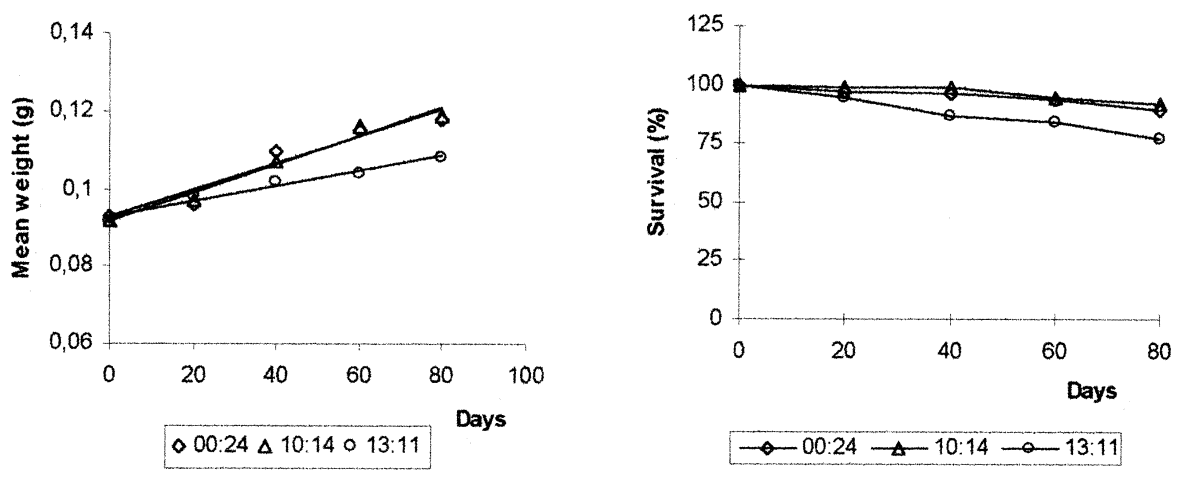

1

Figs. 1, 2. Growth and survival of Palaemonetes argentinus Nobili, 1901 under different photophases, respectively. 
treatments. Molt rate was significantly higher during the longest photophase (MR=1.68) than during the shortest one $(\mathrm{MR}=0.57)$ and than under continuous dark condition $(\mathrm{MR}=0.32)(\mathrm{p}<0.05)$. The lowest survival (fig. 2$)$ was found in animals maintained under 13:11 L-D conditions (77\%), being statistically different of the other two treatments ( $92 \%$ and $89 \%$ at $10: 14$ and $0: 24$, respectively) $(\mathrm{p}<0.05)$.

\section{DISCUSSION}

Most of the studies on the effect of light on crustaceans indicate variable results. Larger increments in size were noted in larvae of Homarus americanus Milne-Edwards, 1837 (AIKEN et al., 1983) when kept in continuous darkness, but this effect has not been observed in other species. Generally, neither the duration nor the intensity of light has been found to affect the molt increment. This aspect was recorded in Panulirus longipes (Milne-Edwards, 1868), Pachygrapsus marmoratus (Fabricius, 1787), larvae of Palaemonetes vulgaris (Say, 1818) and in various other species (HarTnOLL, 1982). In P. argentinus was observed a good weight increment with the three treatments. MASON (1978), working on Pacifastacus leniusculus (Dana, 1852), found that growth was more affected by temperature than by photoperiod.

In the present study, a high survival was recorded at complete darkness and at 10:14 L-D conditions, the last one corresponding to the normal day-length of the locality in autumn. The maximum mortality was observed at the maximum light conditions (13hour light), which correspond to the normal day-length in spring months. The highest mortality was coincident with the highest molting rate $(\mathrm{MR}=1.7)$, which was very high compared to that obtained with the other two treatments. Survival in P. argentinus was more affected by photoperiod than growth; this aspect was also observed in Pacifastacus leniusculus (MASON, 1978). In contrast, GARDNER \& MAGUIRE (1998), in Pseudocarcinus gigas (Lamarck, 1818) larvae, found that survival was not significantly affected by photoperiod.

A long-day photoperiod increases molting rate but causes a greater mortality. Long days shorten the time between molts, which produce lower biomass incorporation due to the high cost of energy that the molt implies. An increase of photoperiod length produces an increase in haemolymph of lactate similar to that produced by exercise and other factors considered as stressors in decapod crustaceans (FANJUL-Moles et al., 1998). Palaemonetes argentinus is not very aggressive and the density in the aquaria was quite low to avoid cannibalism on individuals which had recently moulted. This argument allows thinking that the main cause of death was the stress produced by the high molting rate at 13:11 L-D.

In $P$. argentinus the lowest molting rate occurred in complete darkness. Coincidentally, in Procambarus clarkii (Girard, 1852) submitted to constant darkness, molting inhibition was notorious; probably darkness alters the relationship between the $\mathrm{X}$-organ sinus gland molting-inhibiting hormone $(\mathrm{MIH})$ and the $\mathrm{Y}$-organ molting hormone (MH) (CASTAÑón-CERvantes et al., 1995). Aiken (1969) suggested a stimulating effect of light on the Y-organ of Orconectes virilis (Hagen, 1870), which implies the possibility of a photoperiodic control of the Y-organ which would be missing in absence of light. KURUP (1970) observed in Hemigrapsus nudus (Dana, 1851) that the animals are more resistant to dark environs, though prolonged darkness 
blocks molting altogether. Bishop \& Herrnkind (1976) found in Farfantepenaeus duorarum (Burkenroad, 1939) the highest number of exuviae in complete darkness, indicating that this species might have an endogenous molt rhythm in the absence of light.

The best growth and survival in $P$. argentinus was observed in a 10:14 L-D cycle, recording an intermediate molting rate, and that the growth was less affected by photoperiod than molting rate and survival. Molting in $P$. argentinus does not require a particular photoperiod but photoperiod, drives the annual molt cycle. This control of molting is clearly evident in responses of prawns maintained under normal photoperiods, the short-day period (10:14 L-D) of the yearly cycle reduces the frequency of molting and the long-day period (13:11 L-D) increases molting. Under the experimental conditions, survival was clearly affected by an increase of the photophase length.

\section{REFERENCES}

Aiken, D. E. 1969. Photoperiod, endocrinology and the crustacean molt cycle. Science, New York, 164:149-155.

Aiken, D. E.; Martin Roubichaud, W. J. \& Waddy, S. L. 1983. Seasonal differences in the effects of photoperiod on survival and development of larval American lobsters (Homarus americanus). J. World Maricul. Soc., Baton Rouge, 13:287-293.

Bishop, J. M. \& Herrnkind, W. F. 1976. Burying and molting of pink shrimp, Penaeus duorarum (Crustacea: Penaeidae), under selected photoperiods of white light and UV-light. Biol. Bull., Woods Hole, 150(2):163-182.

Bond-Buckup, G. \& Buckup, L. 1989. Os Palaemonidae de águas continentais do Brasil meridional (Crustacea, Decapoda). Revta bras. Biol., Rio de Janeiro, 49(4):883-896.

Castañón-Cervantes, O.; Lugo, C. et al. 1995. Photoperiodic induction on the growth rate and gonads maturation in the crayfish Procambarus clarkii during ontogeny. Comp. Biochem. Physiol., Oxford, 110A(2):139-146.

Dalley, R. 1980. The survival and development of the shrimp Crangon crangon (L.), reared in the laboratory under non-circadian ligth-dark cycles. J. exp. mar. Biol. Ecol., Amsterdan, 47:101112.

Destefanis, S. \& Freyre, R. 1972. Relaciones tróficas de los peces de la laguna de Chascomús con un intento de referenciación ecológica y tratamiento bioestadístico del espectro trófico. Acta zool. lilloana, Tucumán, 29:17-53.

Díaz, A. C.; Petriella, A. M. \& Sousa, L. G. 1998. Setogenesis and growth of the freshwater prawn Palaemonetes argentinus (Decapoda, Caridea, Palaemonidae). Iheringia, Sér. Zool., Porto Alegre, (85):59-65.

Díaz, A. C.; Sousa, L. G. \& Petriella, A. M. 2001. Growth of the prawn, Palaemonetes argentinus Nobili, 1901 (Decapoda, Palaemonidae) on different feeds. Crustaceana, Leiden, 74(9):861-870.

Fanjul-Moles, M. L.; Bosques-Tistler, T. et al. 1998. Effect of variation in photoperiod and light intensity on oxygen consumption, lactate concentration and behaviour in crayfish Procambarus clarkii and Procambarus digueti. Comp. Biochem. Physiol., Oxford, 119A(1):263-269.

Gardner, C. \& Maguire, G. B. 1998. Effect of photoperiod and ligth intensity on survival, development and cannibalism of larvae of the Australian giant crab Pseudocarcinus gigas (Lamark). Aquaculture, Amsterdan, 165:52-63.

Guary, J. C.; Kayama, M. \& Murakami, Y. 1974. Lipid class distribution and fatty acids composition of prawn, Penaeus japonicus Bate. Bull. Jap. Soc. Sci. Fish., Tokyo, 40(10):1027-1032.

Hartnoll, R. G. 1982. Growth. In: Bliss, D. ed. The biology of Crustacea. New York, Academic. V. 2, p. 111-185.

Hoffman, K. 1981. Photoperiodism in Vertebrates. In: Aschoff, J. ed. Handbook of behavioural neurobiology. New York, Plenum. v. 4, p. 449-474. 
Kurup, N. G. 1970. Effects of photoperiod on molting in Hemigrapsus nudus Dana. Curr. Sci., Bangalore, 39(7):149-151.

Mason, J. C. 1978. Effects of temperature, photoperiod, substrate, and shelter on survival, growth and biomass accumulation of juvenile Pacifastacus leniusculus in culture. Freshwat. Crayfish, Hinterthal, 4:73-82.

Passano, L. M. 1960. Molting and its control. In: Watermann, T. ed. Physiology of Crustacea. New York, Academic. v. 1, p. 473-536.

SAUndERs, D. S. 1975. Skeleton photoperiods and control diapause and development in the flesh-fly Sarcophaga argyrostoma. J. Comp. Physiol., New York, 97:97-112.

Seagal, E. 1970. Light, invertebrates. In: Kinne, O. ed. Marine Ecology. London, WileyInterscience. v. 1, p. 159-211.

Sokal, R. R. \& Rohlf, F. J. 1995. Biometry, the principles and practice of statistics in biological research. New York, W.H. Freeman. 887p.

Tidwell, H. J.; D'Abramo, L. R. et al. 1996. A standardized comparison of semi-intensive pond culture of freshwater prawns Macrobrachium rosenbergii at different latitudes: production increases associated with lower water temperatures. Aquaculture, Amsterdan, 141:145-158.

Recebido em 23.09.2002; aceito em 08.05.2003.

Iheringia, Sér. Zool., Porto Alegre, 93(3):249-254, 30 de setembro de 2003 